\title{
Dødelig skam
}

\author{
Tekst og foto: Ingeborg Vea
}

\section{-Tanken på selvmord var en overordnet idé og et bærende element for meg, like selvfølgelig som å puste. Etter hvert ble selvmordstankene altoverskyggende, forteller Anne Marie Svebak Johnsen.}

Som 20-åring ble Anne Marie (34) utsatt for grove seksuelle overgrep. Hun søkte hjelp, men fikk det ikke. Tanken på selvmord hjalp henne å holde ut den første tiden, forteller hun.

- Etter overgrepene kom tanken på selvmord umiddelbart. Mest fordi jeg følte meg helt $\mathrm{d} \varnothing \mathrm{d}$ etter at det var over, jeg var nummen og helt utenfor alt, men også fordi jeg trodde helt konkret mens det pågikk at jeg ikke ville overleve selve voldtektene. Derfor "var jeg allerede død". Likevel var tanken på selvmord i liten grad knyttet til gjennomføring. Tanken var mitt "fristed", en beroligende visshet om at det var en vei ut, en fluktvei. Sånn sett var selvmordstanken "god" i tiden rett etterpå, forteller Anne Marie.

\section{Ville klare seg selv}

Anne Marie skammet seg over selve voldtektene, og over at hun ikke gikk til anmeldelse.

- Jeg holdt på å dø av skam. Skammen bredte seg som en tåke i sjelen. Først lå den som et tett skylag, men sakte gjennomtrengte den alt. Jeg var fast bestemt på å ikke la voldtektene фdelegge livet for meg. Jeg ville videre. Tenkte at på et punkt skulle jeg klare å komme i vater. Jeg var opptatt av at dette var mitt ansvar. I vårt samfunn vektlegges det materielle og psykiske overskuddet. Lidelse er en utgiftspost som bare verdsettes dersom den ender i noe fantastisk.

Anne Marie utviklet en såkalt "dissosiativ tilstand".

H un delte sjelen, som hun sier, og levde to liv. E tt som om ikke overgrepene hadde skjedd. D et andre, godt skjult for omgivelsene, hvor reaksjonene etter overgrepene var stuet bort.

- Jeg hadde en voldsom selvdisiplin. Brukte masse krefter på å administrere egne reaksjoner. Det ble mange løgner, om jobb, studier og så videre. Etter hvert ble det mye å holde styr på. Jeg fikk konsentrasjonsproblemer og slet med tilbakevendende depresjoner. Sammen med andre klarte jeg å yte noe, men alene, som for eksempel i en eksamenssituasjon, hadde jeg problemer, forteller hun.
Ti år etter katastrofehendelsen begynte Anne Marie å miste kontrollen.

- Jeg hadde problemer med jobb og фkonomi, og slet med selvfølelsen. Jeg var sliten inn til margen. Selvmordstankene var blitt til tvangstanker ute av kontroll, og en nødvendig, logisk konsekvens av alle mine nederlag.

Uten forvarsel oppdaget Anne Marie at hun var halvgått $i$ et svangerskap.

- Dette var i etterkant av drapene i Baneheia. Den ene av jentene var i slekt med mannen min, og dermed kom hendelsen veldig nær oss. Jeg ble akutt suicidal.

Anne Marie kom raskt i kontakt med Josefinegate DPS på Frogner i Oslo, og begynte i samtaleterapi.

- Jeg opplevde tre mirakler. Det første mirakelet var behandleren jeg fikk. Hun var både en dyktig fagperson og et klokt menneske. Det var av uvurderlig betydning at jeg traff akkurat henne akkurat da.

Som følge av graviditeten var behandlingen tett samtaleoppfølging og ikke medikamenter.

- For meg var fremtidsperspektivet begrenset til å holde meg i live til barnet ble født. Jeg manglet fullstendig selvtillit og hadde ingen tro på meg selv som mor. Jeg fikk også samtaletilbud tilknyttet

Gaia-prosjektet ved Ullevål sykehus, som er samtaletilbud med jordmor for kvinner med ekstrem fødselsangst. Det var mirakel nummer to. Jeg var livredd selve fødselen, for at den skulle trigge selve voldtektsopplevelsene. Tanken på å få en jente var også skremmende. Jeg hadde fryktelige fantasier om at en datter skulle oppleve det samme som meg.

\section{Tilbake til livet}

Det tredje mirakelet for Anne Marie var SPOR, et sysselsettingstiltak for personer med psykiske funksjonshemninger i Frogner bydel i Oslo, som nå er nedlagt. Der begynte hun mens hun fortsatt var gravid.

- De hadde et sterkt fokus på brukernes egne ressurser, og "tvang" meg fra første møte til å tenke gjennom hvilke erfaringer jeg hadde som kunne brukes videre. Det var fullstendig fjernt for meg da jeg kom dit. De stilte krav, men tempoet styrte jeg. Jeg har virkelig jobbet så hardt! De gav meg anerkjennelse for arbeidet jeg gjorde, både med meg selv og med tingene rundt meg. Min st $\varnothing$ ttespiller i SPOR fungerte som en slags koordinator overfor trygdekontor og Aetat, motiverte meg til å delta i Frivillighetssentralen og benytte meg av Åpen barnehage i spedbarnstiden. Senere fikk jeg hjelp til blant annet å s $\varnothing$ ke barnehageplass, og dermed sette planer om utdannelse og jobb ut $\mathrm{i}$ livet, sier Anne Marie.

Sammen med st $\varnothing$ ttespilleren i SPOR laget hun en individuell og gjennomarbeidet handlingsplan. Målet var å unngå nye nederlag. Hvilket arbeid kunne hun tenke seg? Og hvordan komme dit? Gjennom SPOR fikk hun også hjelp til å finne veien gjennom de ulike st $\varnothing$ nadsordningene, fra sykepenger til fødselspenger til rehabiliteringspenger, attføring og til slutt hospitering på Norsk Folkemuseum høsten 03.

I dag har Anne Marie et engasjement i publikumsavdelingen på Norsk Folkemuseum. En jobb som passer godt med

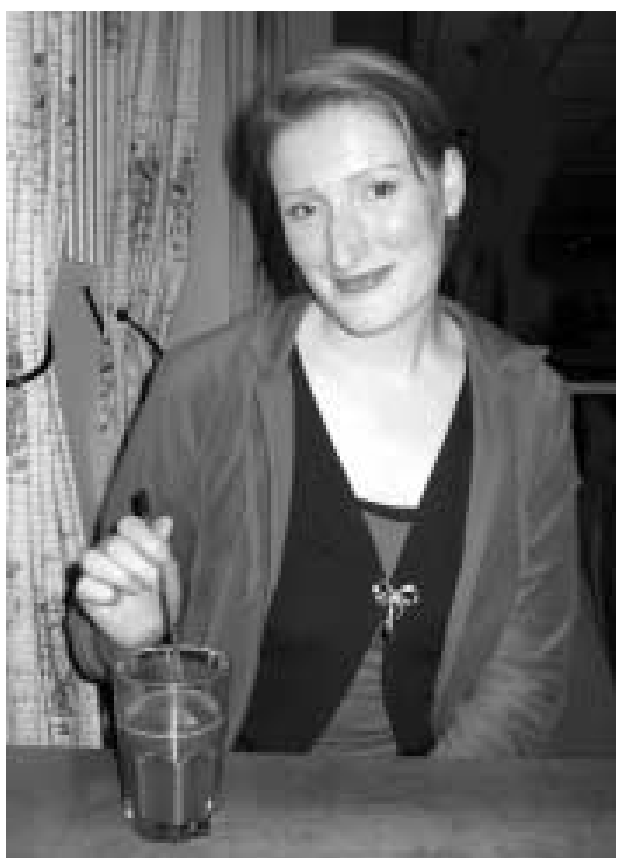

- J eg skammer meg ikke lenger, men er stolt over arbeidet jeg har gjort og inderlig takknemlig for hjelpen jeg fikk da jeg trengte den mest, sier A nne $M$ arie Svebak Johnsen 


\section{Nye bøker}

hennes bakgrunn fra teater og kunstformidling.

- Det er inspirerende å se min egen fremgang. På Folkemuseet har jeg hele tiden fått reelle arbeidsoppgaver som avspeiler min fremgang og utvikling både faglig og personlig. Det er inspirerende!

\section{Et helt liv}

Anne Marie synes det er vanskelig å peke på noe konkret vendepunkt i sin historie. St $\varnothing t t e n$ fra mannen hennes og nær familie har vært avgjørende. Viktigst var likevel fødselen av sønnen Johannes. - Tanken på fødselen var svært traumatisk for meg. Jeg ble tvunget til å forholde meg til min egen kropp. Mitt mål hadde vært å holde meg i live til Johannes ble født, men når han kom ble han en liten motor, en grunn til å holde meg i live fra den ene dagen til den andre. Lille Johannes har ikke vært "mammas redningsplanke", men hvis du er alene i skogen og er redd, men har med deg en som er mer sårbar enn deg selv, blir du litt toffere.

Anne Marie understreker at ikke alt bare var fælt de ti årene fra overgrepene skjedde til hun startet samtaleterapien. - Jeg kunne glede meg over hyggelige hendelser, over mannen min, venner og familie. Den store forskjellen er at jeg i dag lever et helt liv. Det rommer både det bittelille og det veldig store. Jeg opplever endelig å ha reell innvirkning på livet mitt. Før var det så mange ting som preget meg at jeg ikke hadde styringen selv. Jeg har også godtatt at jeg må bære med meg den katastrofale hendelsen resten av livet. Men samtaleterapien har hjulpet meg å pakke sekken riktigere, slik at den er lettere å bære. Jeg skammer meg ikke lenger, men er stolt over arbeidet jeg har gjort og inderlig takknemlig for hjelpen jeg fikk da jeg trengte den mest.

Selvmordstankene dukker ikke lenger opp automatisk.

- Det er befriende! Imidlertid er jeg bevisst på mine egne faresignaler, og tar den kunnskapen med meg videre i det store, ukjente livet, sier Anne Marie.

Ingeborg Vea er informasjons- og markedskoordinator i Organisasjonen Voksne for Barn (VfB), og redakt $\varnothing \mathrm{r}$ for Magasinet Voksne for Barn og medlemsavisen Bulletin.

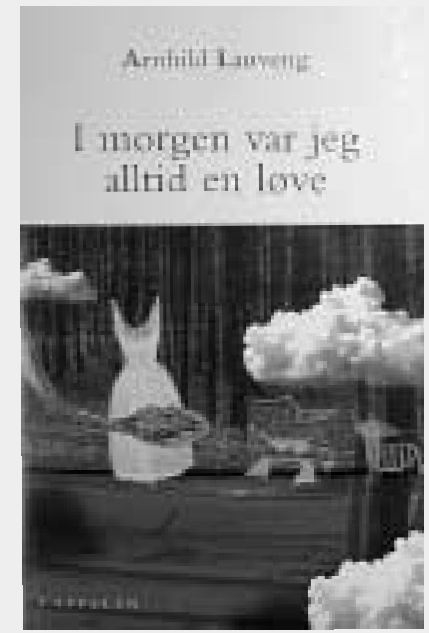

Arnhild Lauveng:

\section{I morgen var jeg alltid en løve.} C appelen 2005.

Arnhild Lauveng fikk diagnosen schizofreni som tenåring og var i mange år innlagt på psykiatriske sykehus. Hun skadet seg selv og levde med hallusinasjoner. I dag er hun frisk og jobber som psykolog. I boka gir hun oss viktige refleksjoner både som pasient og som fagperson. Hun tar oss med inn i en verden av stemmer og hallusinasjoner og viser oss hvordan vrangforestillinger og symptomer har sin egen logikk og mening. Lauveng er en aktiv foredragsholder, og fikk i 2004 "Prisen til fremme av ytringsfriheten i psykisk helsevern".
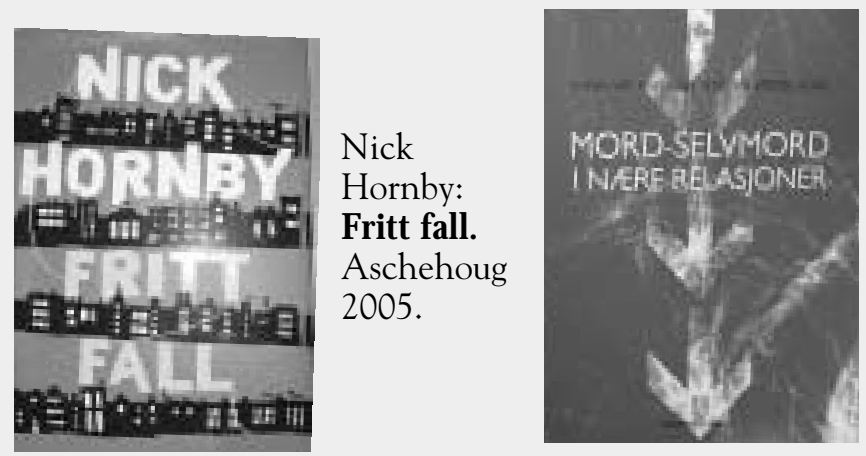

Wik, Gustav/ Galta, Karen/ Olsen, Siri Lerst $\varnothing \mathrm{l}$ M ord - selvmord i nære relasjoner. Universitetsforlaget 2005.

(Lapierre: Ref. forts. fra s. 26.)

Malone, K.M., Oquendo, M.A., Haas, G.L., Ellis, S.P., Li, S., \& Mann, J.J. (2000). Protective factorsagainst suicidal acts in major depression: Reasons for living. American Journal of Psychiatry, 157(7), 1084-1088.

Michel, K. \& Valach, L. (2001). Suicide as goaldirected action. In K. van Heeringen (Ed.), Understanding suicidal behavior (s. 230-254). New York: John Wiley .

Préville, M., Potvin, L., \& Boyer, R. (1995). The structure of psychological distress. Psychological Reports, 77, 275-293.

Roberts. K.T. \& Aspy, C.B. (1993). D evelopment of the Serenity scale. Journal of Nursing Measurement, 1(2), 145-164.

Rothermund, K. \& Brandtstädter, J. (2003).

Depression in later life: C ross-sequential patterns and possible determinants. Psychology and Aging, 18(1), 80-90.

Schmuck, P., \& Sheldon, K.M.(Eds.) (2001). Life $G$ oals and W ell-B eing: Toward a Positive Psychology of $\mathbf{H}$ uman Striving. Seattle: Hogrefe $\&$ Huber Publishers.
Snyder, C.R. \& Rand, K. (2004). H opelessness and health. I N. Anderson (Ed.), Encyclopedia of health and behaviour-Vol. 2 (s. 521-523). Thousands Oaks, CA : Sage.

Snyder, C. R., Sympson, S. C., Ybasco, F. C., Borders, T. F. Babyak, M. A, \& Higgins, R. L. (1996). D evelopment and validation of the state hope scale. J. Pers. Soc. Psy., 70 (2), 321-335.

Stones, M. J., Kozma, A., Hirdes, J., Gold, D., Arbukle, T., \& Kolopack, P. (1996). Short happiness and affect protocol (SH A R P). Social Indicators Research, 34, 75-91.

Watson, D. L., \& Tharp, R. G. (1997). Selfdirected behavior. Pacific Grove, CA: Brooks/Cole.

Yesavage, J.A., Brink, T.L., Rose, T.L., Lum, O., Huang, V., Adey, M., Leirer, V.O. (1983). $D$ evelopment and validation of a geriatric depression screening scale: A preliminary report. Journal of Psychiatric Research, 17(1), 37-49. 